\title{
Ribosomal Function Inhibition
}

National Cancer Institute

\section{Source}

National Cancer Institute. Ribosomal Function Inhibition. NCI Thesaurus. Code C45554.

Ribosomal Function Inhibition is a process that prevents normal translation, typically by interfering with ribosomal protein subunits or RNA components. 